\title{
Synthesis and Characterization of a $\mathrm{Fe}_{3} \mathrm{O}_{4} @ P N I P A M-C h i t o s a n$ Nanocomposite and Its Potential Application in Vincristine Delivery
}

\author{
Cynthia N. Hernández-Téllez ${ }^{1}{ }^{(D}$, Ana G. Luque-Alcaraz ${ }^{1}$, Maribel Plascencia-Jatomea ${ }^{2}{ }^{\circledR}$,
} Hiram J. Higuera-Valenzuela ${ }^{1}$, Mabeth Burgos-Hernández ${ }^{3}$, Nadia García-Flores ${ }^{4}$, Mario E. Álvarez-Ramos ${ }^{4}$, Jorge L. Iriqui-Razcon ${ }^{1} \mathbb{D}$, Reynaldo Esquivel Gonzalez ${ }^{5}$ and Pedro A. Hernández-Abril ${ }^{1, *} \mathbb{B}$

1 Ingeniería Biomédica, Universidad Estatal de Sonora, Hermosillo 83100, Mexico; cynthia.hernandez@ues.mx (C.N.H.-T.); ana.luque@ues.mx (A.G.L.-A.); hiram.higuera@ues.mx (H.J.H.-V.); jorge.iriqui@ues.mx (J.L.I.-R.)

2 Departamento de Investigación y Posgrado en Alimentos, Universidad de Sonora, Hermosillo 83000, Mexico maribel.plascencia@unison.mx

3 Licenciatura en Ecología, Universidad Estatal de Sonora, Hermosillo 83100, Mexico; mabeth.burgos@ues.mx

4 Departamento de Física, Universidad de Sonora, Hermosillo 83000, Mexico; nadian.garciafl@gmail.com (N.G.-F.); enrique.alvarez@fisica.uson.mx (M.E.Á.-R.)

check for

updates

Citation: Hernández-Téllez, C.N.;

Luque-Alcaraz, A.G.;

Plascencia-Jatomea, M.;

Higuera-Valenzuela, H.J.

Burgos-Hernández, M.; García-Flores,

N.; Álvarez-Ramos, M.E.

Iriqui-Razcon, J.L.; Gonzalez, R.E.;

Hernández-Abril, P.A. Synthesis and

Characterization of a

$\mathrm{Fe}_{3} \mathrm{O}_{4} @$ PNIPAM-Chitosan

Nanocomposite and Its Potential

Application in Vincristine Delivery.

Polymers 2021, 13, 1704. https://

doi.org/10.3390/polym13111704

Academic Editor: Dimitrios Bikiaris

Received: 2 May 2021

Accepted: 20 May 2021

Published: 23 May 2021

Publisher's Note: MDPI stays neutral with regard to jurisdictional claims in published maps and institutional affiliations.

Copyright: (c) 2021 by the authors. Licensee MDPI, Basel, Switzerland. This article is an open access article distributed under the terms and conditions of the Creative Commons Attribution (CC BY) license (https:// creativecommons.org/licenses/by/ $4.0 /)$
5 Laboratorio de Investigacióny Desarrollo, CREST Norteamerica, Santa Catarina 66350, Mexico; reynal-doegzz@gmail.com

* Correspondence: pedro.hernandez@ues.mx

\begin{abstract}
In this research, we conducted a systematic evaluation of the synthesis parameters of a multiresponsive core-shell nanocomposite $\left(\mathrm{Fe}_{3} \mathrm{O}_{4}\right.$ nanoparticles coated by poly(N-isopropylacrylamide) (PNIPAM) in the presence of chitosan (CS) $\left(\mathrm{Fe}_{3} \mathrm{O}_{4} @\right.$ PNIPAM-CS). Scanning electron microscopy (SEM) was used to follow the size and morphology of the nanocomposite. The functionalization and the coating of $\mathrm{Fe}_{3} \mathrm{O}_{4}$ nanoparticles (Nps) were evaluated by the $\zeta$-potential evolution and Fourier Transform infrared spectroscopy (FTIR). The nanocomposite exhibited a collapsed structure when the temperature was driven above the lower critical solution temperature (LCST), determined by dynamic light scattering (DLS). The LCST was successfully shifted from 33 to $39^{\circ} \mathrm{C}$, which opens the possibility of using it in physiological systems. A magnetometry test was performed to confirm the superparamagnetic behavior at room temperature. The obtained systems allow the possibility to control specific properties, such as particle size and morphology. Finally, we performed vincristine sulfate loading and release tests. Mathematical analysis reveals a two-stage structural-relaxation release model beyond the LCST. In contrast, a temperature of $25^{\circ} \mathrm{C}$ promotes the diffusional release model. As a result, a more in-depth comprehension of the release kinetics was achieved. The synthesis and study of a magnetic core-shell nanoplatform offer a smart material as an alternative targeted release therapy due to its thermomagnetic properties.
\end{abstract}

Keywords: drug delivery; nanocomposite; chitosan; PNIPAM; vincristine; magnetite

\section{Introduction}

Nanometric scale research has opened a promising perspective on understanding the behavior of matter at this level. It has been observed that, at regular or macro size, the properties of a material with the same chemical composition are different than when presented as nanostructures [1]. Its main outstanding property is the increase in surface contact because hundreds of atoms are located on the surface of the nanostructures, available to react per square centimeter. Recently, these nanostructures and their properties are beginning to be used regularly, as they can be applied in a wide range of disciplines. In modern medicine, the application of nanostructures in different forms has been proposed: nanoparticles as biomarkers for imaging [2], magnetic hyperthermia [3], arrays as drug delivery systems [4], charged magnetic particles proposed as targeted therapy, and drug 
release as is the case in this study. The development of modern technology for its practical application and performance requires intelligent materials to innovate and lead different challenges such as biophysics [5], aerospace [6], biotechnology [7], biomedicine [8], among other current challenges $[9,10]$, versatile materials that represent a challenge for nanoscience and nanotechnology. Among the smart materials, CS can be highlighted, widely known, and applied in biomedicine due to its biocompatibility, biodegradability, and adhesiveness, among other favorable properties. CS is an N-deacetylated derivative of chitin, which is commercially present in different degrees of deacetylation and different molecular weights. Due to its basic character and a 6.2-7.0 pK, it is insoluble in many aqueous solutions, making it challenging to apply in neutral or alkaline environments. That is why CS can undergo different modifications to increase its physicochemical properties such as solubility, porosity, and architectural forms, among others [11].

On the other hand, PNIPAM is an intelligent thermosensitive material because it can change its structural conformation under temperature variations of a few degrees Celsius (32 ${ }^{\circ} \mathrm{C}$ approximately), known as its LCST, originating new properties of the material undergoing these temperature changes. This characteristic can be exploited and applied as micelles or vesicles for drug delivery [4]. Increasing the LCST of the material close to the organism's body temperature $\left(37^{\circ} \mathrm{C}\right.$ approximately) allows a better-controlled release once internalized as a drug release platform. Increasing the LCST of PNIPAM can be achieved by adding a polymer such as CS to the nanoplatform, increasing the material's biodegradability since PNIPAM shows high chemical stability, thus achieving fractional degradation [12].

One of the most significant challenges of drug or radioisotope delivery treatments in the organism is to avoid damage to healthy cells and reduce toxicity [13]. The inclusion of magnetite $\left(\mathrm{Fe}_{3} \mathrm{O}_{4}\right)$ to a nanoplatform gives it the property of bio-directing [14] and locating the particle towards a specific tissue or cells [15]; in addition, it is well tolerated by the organism and susceptible to biopolymer coatings to be biocompatible [16]. All of the above allows biomedicine to use $\mathrm{Fe}_{3} \mathrm{O}_{4}$ by hyperthermia, a complementary therapeutic procedure based on the increase in temperature in a tumor mass using this type of nanostructures; Jasso-Terán et al. reported an increase in temperature of magnetic nanoparticles of $41.2^{\circ} \mathrm{C}$, simulated under physiological conditions in vitro [17].

One of the most important aspects of a drug delivery platform is biocompatibility [18]. Multiple studies report high toxicity of magnetite [19,20]; however, as they are coated with biocompatible polymers such as PNIPAM and CS, this parameter is increased [21,22]. Kean and Thanou (2010) report that when supplying CS and its derivatives intravenously, the distribution route is initially in the liver and lung during the first $60 \mathrm{~min}$ [23], then in these organs the enzymes such as lysozyme and chitin start the degradation of this polymer [24]. Briceño et al., (2017) report a study of magnetite nanoparticle degradation in a biomimetic medium; this study shows that nanoparticles that were not covered with OA show rapid degradation in the first $24 \mathrm{~h}$, while those that were coated with OA show slow degradation of up to $480 \mathrm{~h}$ [25]. For all the above, these materials show desirable characteristics of biocompatibility and biodegradability in a platform for drug delivery.

Additionally, by internalizing and precisely localizing a nanoplatform in the organism, a compound can be released into a target tissue to perform a specific action [26-28]. In this study, vincristine coupled to the nanocomposite is proposed as cancer therapy and targeted release. Vincristine is one of the fundamental cancer treatments, due to its well-defined mechanism of action, in addition to its proven anticancer activity. Its effectiveness against childhood leukemia has been proven in potentially fatal childhood hemangiomas [29,30]. Silverman \& Deitcher (2013) reported that injecting vincristine in the form of a liposomebased on sphingomyelin nanoparticles and cholesterol to the organism exceeds the dosage pharmacokinetics of standard vincristine, delivering an amount of active drug to the target tissues and showing superior antitumor activity [31]. The synthesis and study of a thermo-magnetic core-shell nanoplatform represent a smart thermosensitive material as an alternative targeted release therapy in the organism due to its thermomagnetic properties. 


\section{Materials and Methods}

\subsection{Materials}

The materials used were: $\mathrm{N}, \mathrm{N}^{\prime}$-methylenebisacrylamide (BIS) $154.17 \mathrm{~g} / \mathrm{mol}(99.5 \%), \mathrm{N}-$ isopropylacrylamide (NIPAM) $113.16 \mathrm{~g} / \mathrm{mol}(98 \%$ ), ammonium persulfate (APS) $228.20 \mathrm{~g} / \mathrm{mol}$ $(98 \%)$, sodium dodecyl sulfate (SDS) ( $\geq 99 \%)$, iron(II) chloride $\left(\mathrm{FeCl}_{2}\right)(\geq 98 \%)$, iron(III) chloride $\left(\mathrm{FeCl}_{3}\right)(97 \%)$, oleic acid $(\mathrm{OA})(\geq 99 \%)$, and sodium hydroxide $(\mathrm{NaOH})(\geq 98 \%)$. Chemical reagents were obtained from Sigma-Aldrich (St. Louis, MO, USA). Deionized water $(18.25 \mathrm{M} \Omega / \mathrm{cm})$ was used in all experiments. Nitrogen gas was obtained from a local supplier.

\subsection{Synthesis of $\mathrm{NpFe}_{3} \mathrm{O}_{4}$}

The $\mathrm{NpFe}_{3} \mathrm{O}_{4}$ was synthesized by the iron salts coprecipitation method by adding $\mathrm{NaOH}$ under oxygen-free environments [21]. A solution of $\mathrm{FeCl}_{3}$ and $\mathrm{FeCl}_{2}$ (2:1 molar ratio) was placed into $20 \mathrm{~mL}$ deionized water. The solution was mechanically stirred at $700 \mathrm{rpm}$ while nitrogen gas flowed into the flask for $30 \mathrm{~min}$, resulting in the oxygen's displacement. The solution temperature rose to $70{ }^{\circ} \mathrm{C}$; after $15 \mathrm{~min}$, the color turned yellow to wine-red. The next step was adding $10 \mathrm{~mL}$ of $\mathrm{NaOH}(30 \%)$, turning the color from wine-red to black, indicating the formation of magnetite Nps. Afterward, OA was added to the reaction solution in a 1:1.5 molar ratio $\left(\mathrm{FeCl}_{3}: \mathrm{OA}\right)$, correspondingly. The $\mathrm{OA}$ was exposed to Nps for $15 \mathrm{~min}$ to achieve their stabilization. Lastly, the synthesized Nps were separated from the solution using a neodymium magnet. The solution was separated, and a cleaning process was carried out, first with pure ethanol, then with a $50 \%$ ethanol-water mixture, and ultimately with pure water resulting in a shiny black material.

\subsection{NIPAM Polymerization on $\mathrm{NpFe}_{3} \mathrm{O}_{4}$ in Presence CS ( $\mathrm{Fe}_{3} \mathrm{O}_{4} @ P N I P A M-C S$ )}

In the polymerization, the method of precipitation by free radicals was followed [32]. In the first step, $150 \mathrm{mmol}$ of NIPAM was dissolved in $10 \mathrm{~mL}$ of ultrapure water. Next, $10 \mathrm{mmol}$ of BIS and $20 \mathrm{mmol}$ of SDS were added. $\mathrm{Np}_{0}$ is a sample without CS and $\mathrm{NpFe}_{3} \mathrm{O}_{4}$. $\mathrm{Np}_{1}, \mathrm{~Np}_{2}$, and $\mathrm{Np}_{3}$ are the samples with $\mathrm{NpFe}_{3} \mathrm{O}_{4}$ and molar ratios 1:0, 1000:1, 1000:2, and 1000:3 (NIPAM-CS), respectively. After this, nitrogen gas flowed in the solution flask for $25 \mathrm{~min}$, providing an oxygen-free surrounding. These solutions were warmed to $70^{\circ} \mathrm{C}$. Finally, $1 \mathrm{~mL}$ of $5 \mathrm{mM}$ APS was carefully added. The nitrogen stream and magnetic agitation conditions were maintained for $30 \mathrm{~min}$ at $70{ }^{\circ} \mathrm{C}$. An opalescent solution without polymer additions was observed. The resulting samples were centrifuged fractionally, first at $3000 \mathrm{RPM}$ for $30 \mathrm{~min}$ (separating the uncoated $\mathrm{NpFe}_{3} \mathrm{O}_{4}$ ), then the resulting supernatant at $5000 \mathrm{RPM}$ for $25 \mathrm{~min}$. The resulting pellet was resuspended in ultra-pure water for posterior analyses.

\subsection{Characterization}

The morphologies of $\mathrm{Np}_{0}, \mathrm{~Np}_{1}, \mathrm{~Np}_{2}$, and $\mathrm{Np}_{3}$ were evaluated with the Scanning Electron Microscope (SEM) (JEOL JSM-7800F, Pleasanton, CA, USA) at $3.0 \mathrm{kV}$. The samples were diluted 1 to 15 before deposition on the film. The size distribution of $\mathrm{NpFe}_{3} \mathrm{O}_{4}, \mathrm{~Np}_{0}$, $\mathrm{Np}_{1}, \mathrm{~Np}_{2}$, and $\mathrm{Np}_{3}$ samples was determined by DLS using a Zetasizer-Nano ZS (Malvern Instruments, Malvern, UK), with a laser of wavelength $=633 \mathrm{~nm}(\mathrm{He}-\mathrm{Ne}, 4.0 \mathrm{~mW})$. The $\zeta$-potential of all samples was determined using a sizer-nano ZS (Malvern Instruments, Malvern, UK). The samples' magnetization properties were carried out at $300 \mathrm{~K}$ using a Physical Property Measurement System vibrating Sample Magnetometer (PPMS-VSM, Quantum Design, San Diego, CA, USA); the samples were previously lyophilized. The vincristine sulfate load and release in $\mathrm{Fe}_{3} \mathrm{O}_{4} @$ PNIPAM-CS were measured by indirect quantification using a Perkin Elmer UV-Vis spectrometer (lambda 850, Perkin Elmer Inc., Waltham, MA, USA); the absorbance was fixed at $310 \mathrm{~nm}$. FTIR spectra were collected from a Spectrum (Perkin Elmer, Inc., Waltham, MA, USA) spectrometer equipped with a single diamond attenuated total reflectance (ATR) with a range of $8300-350 \mathrm{~cm}^{-1}$ variable 
IR beam with diameter from 2 to $11 \mathrm{~mm}$. The IR spectra were collected 16 times (spectral resolution $4 \mathrm{~cm}^{-1}$ ).

\subsection{Vincristine Sulfate Loading}

The load vincristine sulfate was determined by subtraction of the initial vincristine solution. The curve of vincristine standards $(0-100 \mu \mathrm{g} / \mathrm{mL})$ was constructed to estimate the amount of free drug in the wash solution. Encapsulation efficiency was determined using the function of vincristine sulfate encapsulated and the initial amount of $\mathrm{Fe}_{3} \mathrm{O}_{4} @ \mathrm{PNIPAM}-\mathrm{CS}$.

\subsection{Vincristine Sulfate Release Study Mathematical Release Model}

The vincristine sulfate release pathway was elucidated by the dialysis tube method. The release mechanism was studied under different temperature conditions. In the first step, $\mathrm{Fe}_{3} \mathrm{O}_{4} @$ PNIPAM-CS-Vincristin pellet was resuspended in $10 \mathrm{~mL}$ of PBS Buffer at a temperature of $37^{\circ} \mathrm{C}$. Sampling was carried out for a prolonged period to observe the details of the release mechanism. All the samples taken were replaced with freshly prepared PBS buffer solution.

Two mathematical models were fitted to the resulting data from the three temperatures. Model 1 is the power-law equation used for releases with a Fickian system [33] (Equation (1)).

$$
\frac{M_{t}}{M_{\infty}}=k_{1} t^{n}
$$

$M \infty$ represents the water intake at the time of equilibrium. The constant $k_{1}$ is the front factor of the swelling ratio. Finally, $n$ is the swelling exponent related to the water sorption mechanism.

Model 2 describes the behavior revealed by the data at 37 and $41{ }^{\circ} \mathrm{C}$; at these temperatures, two release stages are evident; therefore, the BiDoseResp equation was used (Equation (2)).

$$
\frac{M_{t}}{M_{\infty}}=A_{1}+\left(A_{1}-A_{2}\right) *\left\{\left(\frac{p}{1+10^{(\log x 01-x)\left(h_{1}\right)}}\right)+\left(\frac{p-1}{1+10^{(\log x 02-x)\left(h_{2}\right)}}\right)\right\}
$$

This equation was used to model the resistivity as a function of an alloy's temperature [34] and used to describe the fluorescence enhancement behavior with the increase of $\mathrm{pH}$ [35]. Using this model in the release of vincristine is necessary to correlate the parameters of the equation with the physical phenomena involved in the release kinetics. The parameters $h_{1}$ and $h_{2}$ are related to the speed of the release burst in the first and second stage, respectively, and they are directly proportional to the slope of the linear part of the stage. Parameters $A_{1}$ and $A_{2}$ are related to the duration of the first and second stage, respectively. $\log x 01$ and $\log x 02$ represent the proportion released during the plateau between the two stages; the addition of their absolute values is directly proportional to the fraction released during the stage transition.

\section{Results}

\subsection{Swelling Kinetics and LCST}

In this research, the influence of CS concentration in the LCST was tracked and evaluated by the temperature profile using DLS observations. Pure PNIPAM Nps $\left(\mathrm{Np}_{0}\right)$ shows a typical collapse induced by hydrophobic interactions in aqueous media at a temperature of $33^{\circ} \mathrm{C}$. The size of $\mathrm{Np}_{0}$ was about $260 \mathrm{~nm}$ for the swollen state $\left(21^{\circ} \mathrm{C}\right)$ and $103 \mathrm{~nm}$ in a collapsed state $\left(43^{\circ} \mathrm{C}\right)$. The $\mathrm{Np}_{1}$ sample contains the lowest amount of CS. A reduction of the LCST at $31^{\circ} \mathrm{C}$ was observed, attributed to the OA on the $\mathrm{Fe}_{3} \mathrm{O}_{4} \mathrm{Nps}$. An illustrative schematic of the nanocomposite performance and the kinetics of swelling and collapse is shown in Figure 1. 


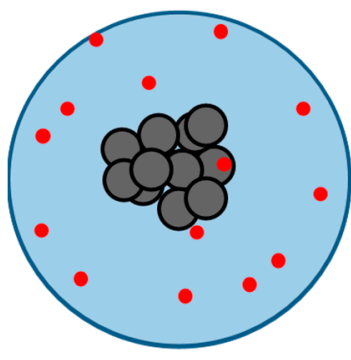

Swollen state

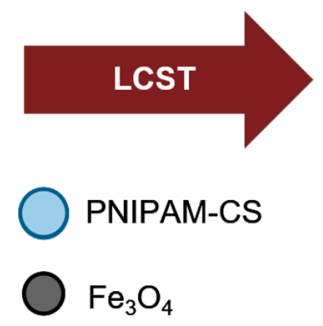

- Vincristine

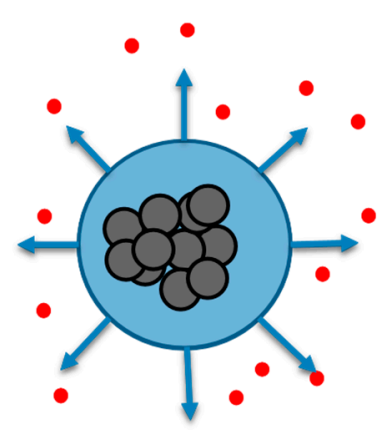

Collapsed state

Figure 1. Illustrative schematic of the nanocomposite $\left(\mathrm{Fe}_{3} \mathrm{O}_{4} @ \mathrm{PNIPAM}-\mathrm{CS}-\right.$ Vincristine) performance and the kinetics of swelling and collapse.

The relatively low molar ratio of CS-PNIPAM allows the influence of OA to prevail. This reduction effect was reported in multiple works [8,36], and we have reported this effect due to the OA in a PNIPAM matrix [21]. In the $\mathrm{Np}_{2}$ and $\mathrm{Np}_{3}$ samples, we observed that the effect of CS predominates because of its greater concentration; the physical integration of the hydrophilic chains of CS leads to the alteration of the hydrophilic/hydrophobic equilibrium. The results indicate a displacement of the LCST to higher values for the samples $\mathrm{Np}_{2}$ and $\mathrm{Np}_{3}\left(33\right.$ and $39^{\circ} \mathrm{C}$ respectively) (Figure 2). The rise of the LCST offers the possibility of focusing its application on releasing drugs into the human body whose internal temperature is around $37^{\circ} \mathrm{C}$. The maximum size in the swollen state $\left(21^{\circ} \mathrm{C}\right)$ of the particles was affected by the presence of CS. The size of the particles $\mathrm{Np}_{1}, \mathrm{~Np}_{2}$, and $\mathrm{Np}_{3}$ at that temperature are 297, 292, and $280 \mathrm{~nm}$, respectively (Figure 2). To explain this behavior, we propose a model in which the spherical particles reached a protonable group saturation stage (amine groups). In this sense, excess amine groups can lead to repulsion between the same groups and generate packaged polymeric structures with more significant spatial restriction. In this way, it is possible to establish the conditions to control the particles' size and LCST as a function of the amount of CS present in the reaction environment. All the above allows us to address design issues concerning Nps with thermal sensitivity and establish the conditions for the internalization of nanoparticles in normal and cancer cell lines.

\subsection{Infrared Spectroscopy Analysis}

In the FTIR spectrum of the $\mathrm{NpFe}_{3} \mathrm{O}_{4}$ sample, a signal is observed around $1562 \mathrm{~cm}^{-1}$ which is related to the $\mathrm{C}=\mathrm{O}$ stretching of a carboxylic acid. In addition, two bands belonging to the $\mathrm{C}=\mathrm{H}_{2}$ group are observed at 2921 and $2853 \mathrm{~cm}^{-1}$ associated with its asymmetric and symmetric stretching, respectively (Figure $3 \mathrm{~b}$ ). The above peaks are characteristic of the OA with which $\mathrm{NpFe}_{3} \mathrm{O}_{4}$ is coated. The bands attributed to OA in the $\mathrm{NpFe}_{3} \mathrm{O}_{4}$ sample do not belong to magnetite because this technique is not sensitive to this compound above $600 \mathrm{~cm}^{-1}$. The above has been reported previously; for example, Chiung-Hua et al., (2020) presented IR spectra of Nps prepared with doxorubicin/gelatin $/ \mathrm{Fe}_{3} \mathrm{O}_{4}$-alginate that showed some characteristic peaks of all components except magnetite for a range of 1000 to $4000 \mathrm{~cm}^{-1}$ [37]. A band is observed around $562 \mathrm{~cm}^{-1}$, attributed to the $\mathrm{Fe}-\mathrm{O}$ vibration of $\mathrm{NpFe}_{3} \mathrm{O}_{4}$ (Figure 3b). The presence of bands related to the $\mathrm{OA}$ functional groups is the first indication of their correct incorporation on the $\mathrm{NpFe}_{3} \mathrm{O}_{4}$ surface. The FTIR analysis of the $\mathrm{Np}_{0}$ sample presents a band in the vicinity of $1630 \mathrm{~cm}^{-1}$; such a signal is related to the carbonyl stretching to the amide group of PNIPAM. Around $3285 \mathrm{~cm}^{-1}$, an absorption related to N-H stretching is present. Finally, a double band at 1366 and $1386 \mathrm{~cm}^{-1}$ due to the isopropyl group of PNIPAM is present (Figure 3a). 

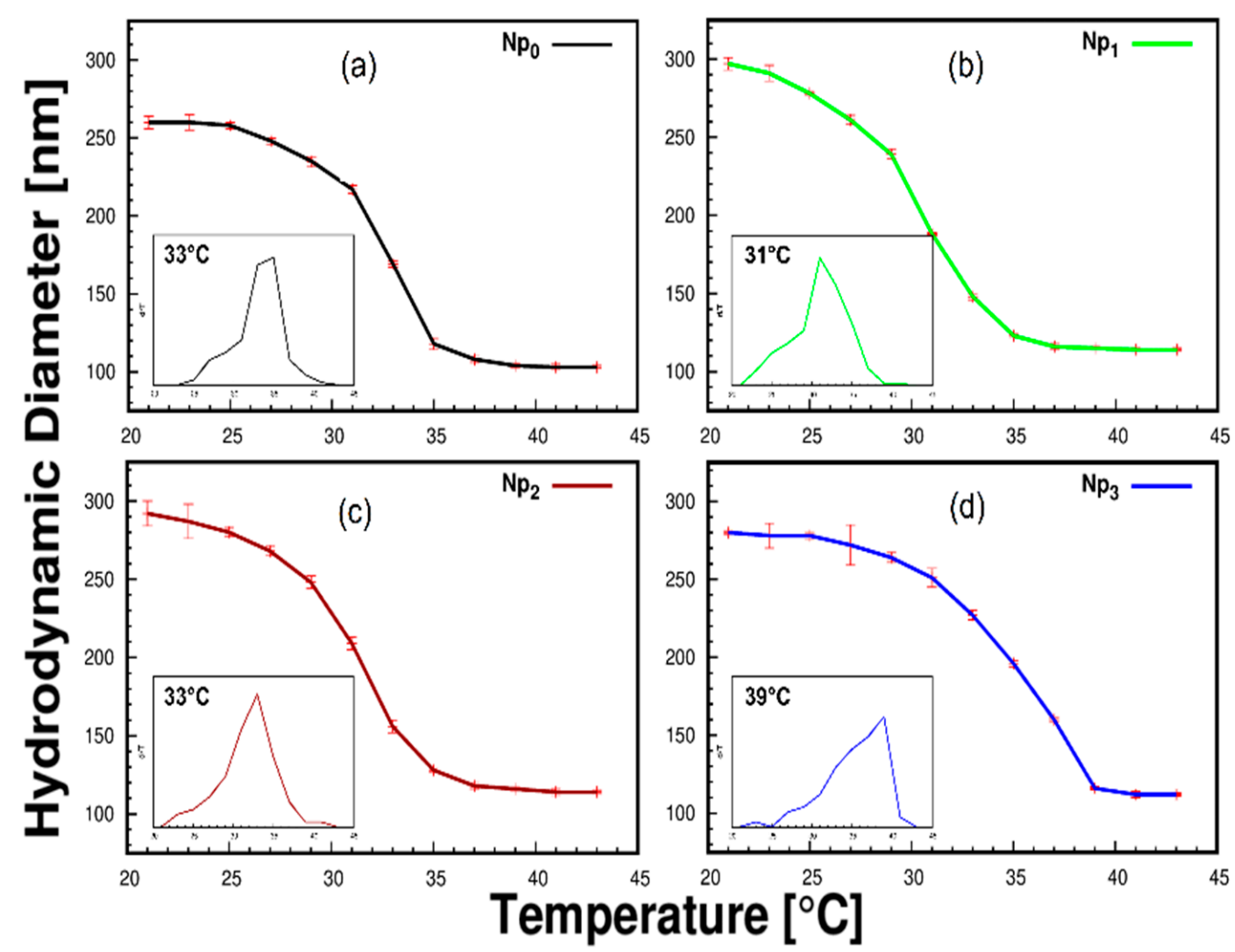

Figure 2. Effect of temperature and nanoparticle sizes of samples (a) $\mathrm{Np}_{0}$; (b) $\mathrm{Np}_{1} ;$ (c) $\mathrm{Np}_{2}$, and (d) $\mathrm{Np}_{3}$ in aqueous media, examined by dynamic light scattering measurements. The temperature values refer to the phase transition. The inset graphics represent the LCST behavior between nanoparticle size and temperature.

The signal related to Fe-O stretching is observed with lower intensity in samples $\mathrm{Np}_{1}, \mathrm{~Np}_{2}$, and $\mathrm{Np}_{3}$, which have the same amount of $\mathrm{NpFe}_{3} \mathrm{O}_{4}$ and demonstrates its correct incorporation into the platform (Figure 3). In samples $\mathrm{Np}_{1}, \mathrm{~Np}_{2}$ and $\mathrm{Np}_{3}$, a small shoulder is observed around $1063 \mathrm{~cm}^{-1}$, attributed to the $\mathrm{C}-\mathrm{O}$ stretching of the CS pyranose ring. This shoulder increases in sample $\mathrm{Np}_{3}$, which contains the most CS. The increase in the signal is directly proportional to the addition of CS, indicating that it is correctly incorporated into the system and that the cleaning processes do not eliminate it. In samples $\mathrm{Np}_{1}, \mathrm{~Np}_{2}$ and $\mathrm{Np}_{3}$, a small shoulder is observed at $1065 \mathrm{~cm}^{-1}$, attributed to C-O stretching of the CS pyranose ring. This shoulder is higher in sample $\mathrm{Np}_{3}$, which contains more CS (Figure 3e). The signal increases as more CS is added in its correct incorporation into the system and as the clean-up processes did not remove it. 


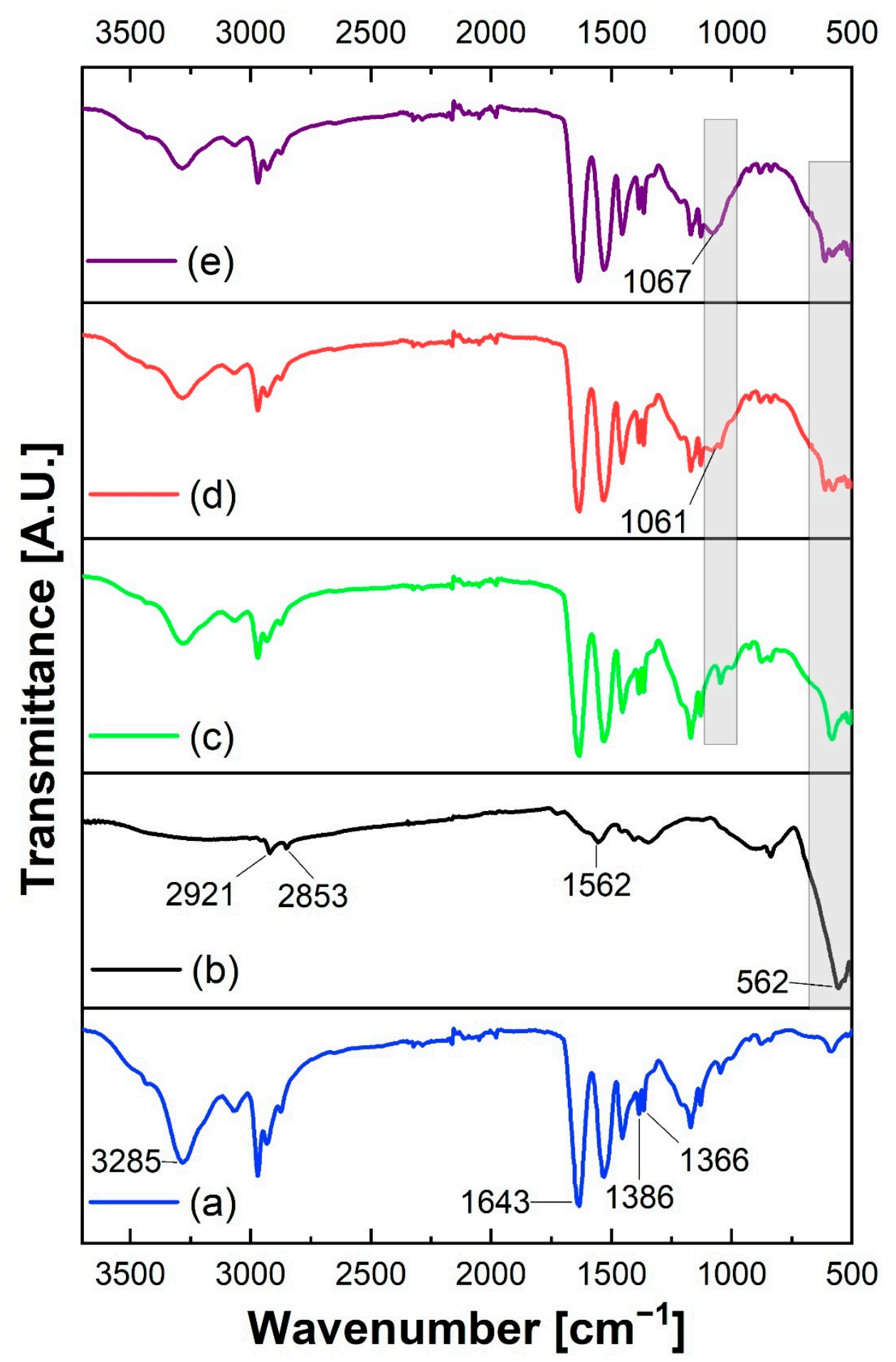

Figure 3. FTIR spectra of vacuum-dried powder of (a) $\mathrm{Fe}_{3} \mathrm{O}_{4} \mathrm{Nps}$, (b) $\mathrm{Np}_{0}$, (c) $\mathrm{Np}_{1}$, (d) $\mathrm{Np}_{2}$, and (e) $\mathrm{Np}_{3}$. They were collected over the wavenumber range of 4000 to $500 \mathrm{~cm}^{-1}$.

\subsection{Magnetic Properties}

Figure 4 presents the hysteresis curves measured at $300 \mathrm{~K}$ of the $\mathrm{Fe}_{3} \mathrm{O}_{4} \mathrm{Nps}$ and $\mathrm{Np}_{3}$ samples. The magnetic saturation values are obtained around 34 and $9 \mathrm{emu} / \mathrm{g}$ for $\mathrm{NpFe}_{3} \mathrm{O}_{4}$ and $\mathrm{Np}_{3}$ samples, respectively. The magnetic properties are strongly correlated with the particle size [38]. Commonly, the superparamagnetic phenomena are exhibited for particles smaller than $10 \mathrm{~nm}$ [39]. Accordingly, considering the particle size achieved, superparamagnetic phenomena should be expected. The phenomenon is evident in the 
$\mathrm{NpFe}_{3} \mathrm{O}_{4}$ sample, given that there is no coercivity, and regardless of the increment in size in the $\mathrm{Np}_{3}$ sample, the same behavior is observed. The obtained values are promising for potential use in biomedical applications; for example, Timur Atabaev et al., (2013) report $34.97 \mathrm{emu} / \mathrm{g}$ and $15.12 \mathrm{emu} / \mathrm{g}$ for bare and core-shell structured samples, respectively [40].

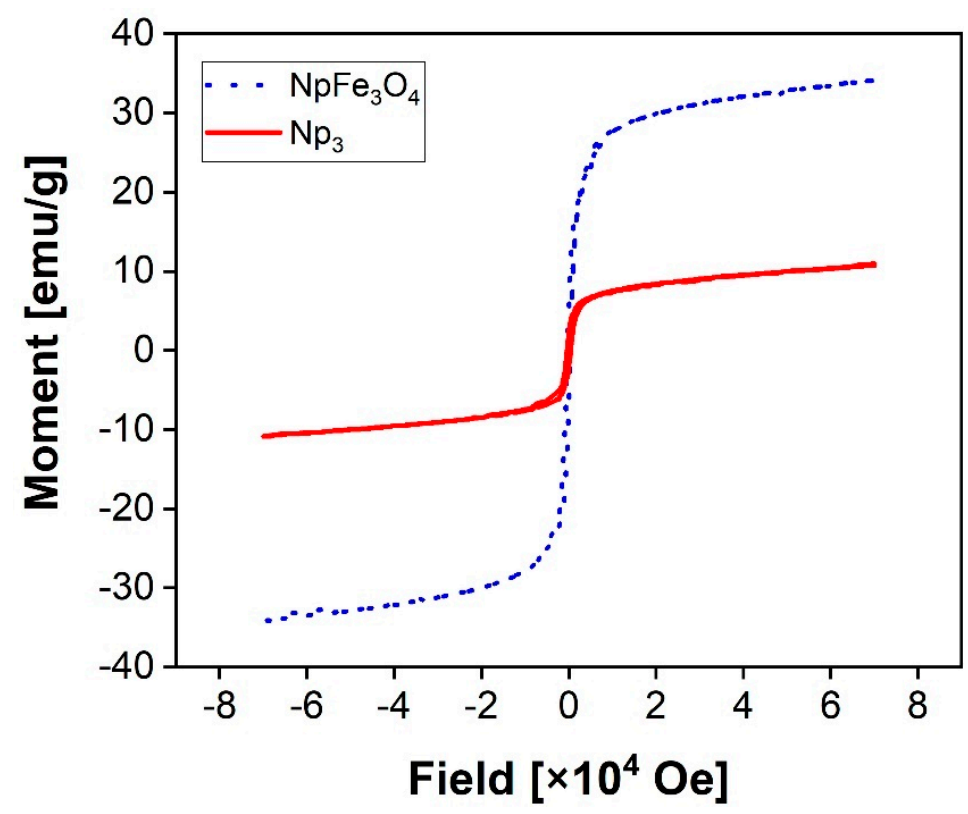

Figure 4. The magnetic curve of $\mathrm{NpFe}_{3} \mathrm{O}_{4}$ and $\mathrm{Np}_{3}$ at $300 \mathrm{~K}$. The hysteresis loops were obtained with a maximum field of $7 \times 10^{4}$ Oe. The samples were previously lyophilized.

All mentioned above allows us to conclude that the superparamagnetic properties were not reduced by the agglomeration of small particles in the core-shell nucleus and enables the synthesized platform to potential biomedical applications in which this property is appreciated.

\section{4. $\zeta$-Potential}

In our case, the magnetite Nps were coated with OA to improve their stability and biocompatibility. The $\zeta$-potential of $\mathrm{Fe}_{3} \mathrm{O}_{4} \mathrm{Nps}$ after the functionalization process was around $7.1 \pm 0.3,18.3 \pm 0.4$, and $24.8 \pm 0.3 \mathrm{mV}$. The electrostatic interactions between the NIPAM monomer and the OA layer resulted in a complex formation. Polymerization of PNIPAM led to an essential change in particle size and $\zeta$-potential. In this way, we confirmed the surface functionalization of $\mathrm{NpFe}_{3} \mathrm{O}_{4}$, and also the increase in the concentration of CS made it possible to obtain nanoparticles with a positive and higher $\zeta$-potential (Figure 5), which benefits its colloidal stability of the nanoparticles and influences the effectiveness of its interaction with negatively charged cell membranes.

The results concorded with Shagholani et al., (2015), who indicated that $\mathrm{Fe}_{3} \mathrm{O}_{4}$ nanoparticles with a $\zeta$-potential of $+36.4 \mathrm{mV}$ had increased positive values of the $\zeta$-potential of CS$\mathrm{Fe}_{3} \mathrm{O}_{4}$ value $(+48.1 \mathrm{mV})$ caused by the CS addition, confirming that functionalization of amino groups on the $\mathrm{Fe}_{3} \mathrm{O}_{4}$ surface by CS molecules [41]. The results obtained in the FTIR analysis showed the presence of $\mathrm{Fe}_{3} \mathrm{O}_{4}, \mathrm{CS}$, and PNIPAM in samples $\mathrm{Np}_{1}, \mathrm{~Np}_{2}$, and $\mathrm{Np}_{3}$. $\mathrm{NpFe}_{3} \mathrm{O}_{4}$ has a negative character; when NIPAM polymerizes in the presence of $\mathrm{NpFe}_{3} \mathrm{O}_{4}$, a $\zeta$-potential close to the isoelectric point is obtained. The above indicates that the PNIPAM character predominates on the surface of the particle. The addition of CS in the reaction results in a positive $\zeta$-potential, and their increase directly proportional to the amount of CS in the reaction indicates that it is interpenetrated to PNIPAM on the surface of the $\mathrm{Fe}_{3} \mathrm{O}_{4}$ particle, forming a core-shell structure. The results indicate electrostatic solid repulsive forces between nanoparticles; this provides good colloidal stability of the suspension since a $\zeta$-potential of this was desired to obtain a physically stable suspension. This positive 
charge facilitates binding nanoparticles with siRNA and DNA plasmids to form complex magnetic nanoparticles for targeting genes delivered into cells [42,43].

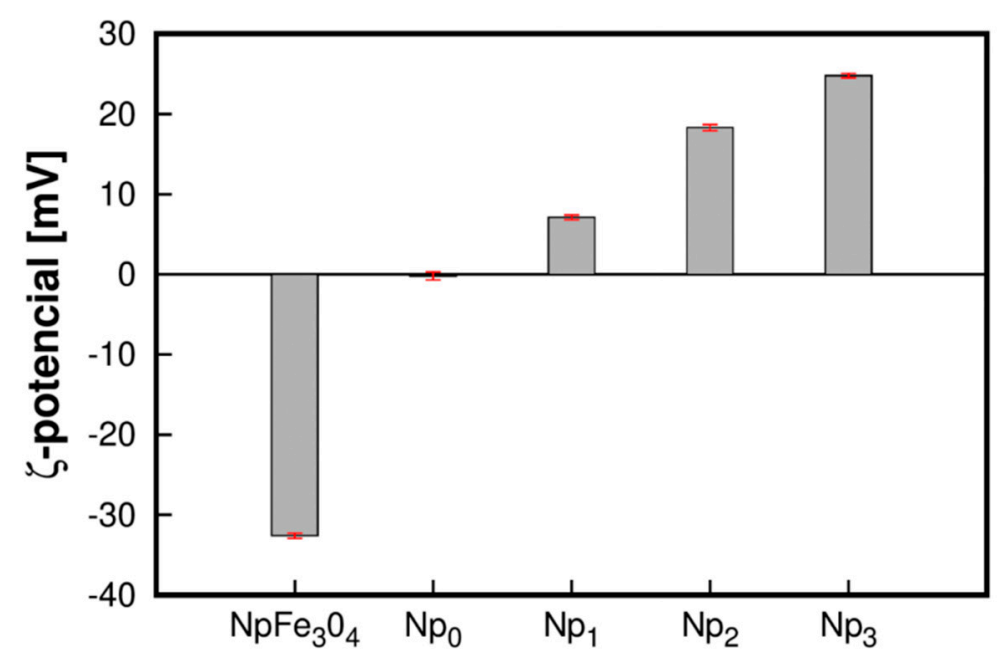

Figure 5. ל-Potential of $\mathrm{Fe}_{3} \mathrm{O}_{4} \mathrm{Nps}$ and samples of $\mathrm{Np}_{0}, \mathrm{~Np}_{1}, \mathrm{~Np}_{2}$, and $\mathrm{Np}_{3}$, determined by sizer-nano ZS.

\subsection{Morphology Analysis}

The shape and size of the nanoparticles $\mathrm{Np}_{0}, \mathrm{~Np}_{1}, \mathrm{~Np}_{2}$, and $\mathrm{Np}_{3}$ were analyzed by SEM and are shown in Figure 6. It can be observed that the sizes of the particles are 208, 304,272 , and $210 \mathrm{~nm}$ for $\mathrm{Np}_{0}, \mathrm{~Np}_{1}, \mathrm{~Np}_{2}$, and $\mathrm{Np}_{3}$, respectively, all presenting a spherical morphology. According to the micrographs, the nanoparticles exhibit a similar shape and structure characteristic of the pure PNIPAM $\left(\mathrm{Np}_{0}\right)$ nanoparticles in all treatments. Likewise, we can highlight from Figure 6 that in the images of $\mathrm{Np}_{1}, \mathrm{~Np}_{2}$, and $\mathrm{Np}_{3}$ the particles present a defined core of magnetite and a shell of PNIPAM. The difference in particle sizes between the different treatments can be attributed to the increase in CS concentration by increasing the amount of CS chains. The phenomenon of steric hindrance occurs, which limits the polymerization of PNIPAM, resulting in particles with smaller sizes; this analysis coincides with that reported by Kang and Kim (2010), who explained that a lower concentration of CS derives a more expanded structure than with pure PNIPAM [44]. The addition of CS shows a trend in reducing the size of the particles, presenting an inversely proportional behavior, since the particle with the highest amount of CS is the one with the minor diameter $\left(\mathrm{Np}_{3}\right.$ $<\mathrm{Np}_{2}<\mathrm{Np}_{1}$ ) compared to that of pure PNIPAM. These observations coincide with what was previously reported by Yi Gong (2012), showing that incorporating CS polymer chains into the PNIPAM particle results in smaller diameter nanoparticles [45]. SEM micrographs allow visualizing in a general way a core-shell morphology; it is observed the lack of core in the $\mathrm{Np}_{0}$ sample, while a higher electron density is observed in the center in the samples containing magnetite. The combined FTIR, $\zeta$-potential, and SEM results allow us to conclude that samples $\mathrm{Np}_{1}, \mathrm{~Np}_{2}$, and $\mathrm{Np}_{3}$ exhibit a core-shell structure. It should be noted that the $\mathrm{Np}_{3}$ treatment (particles of smaller diameter) was selected to perform vincristine release analysis due to its characteristics to act as a release vehicle. 

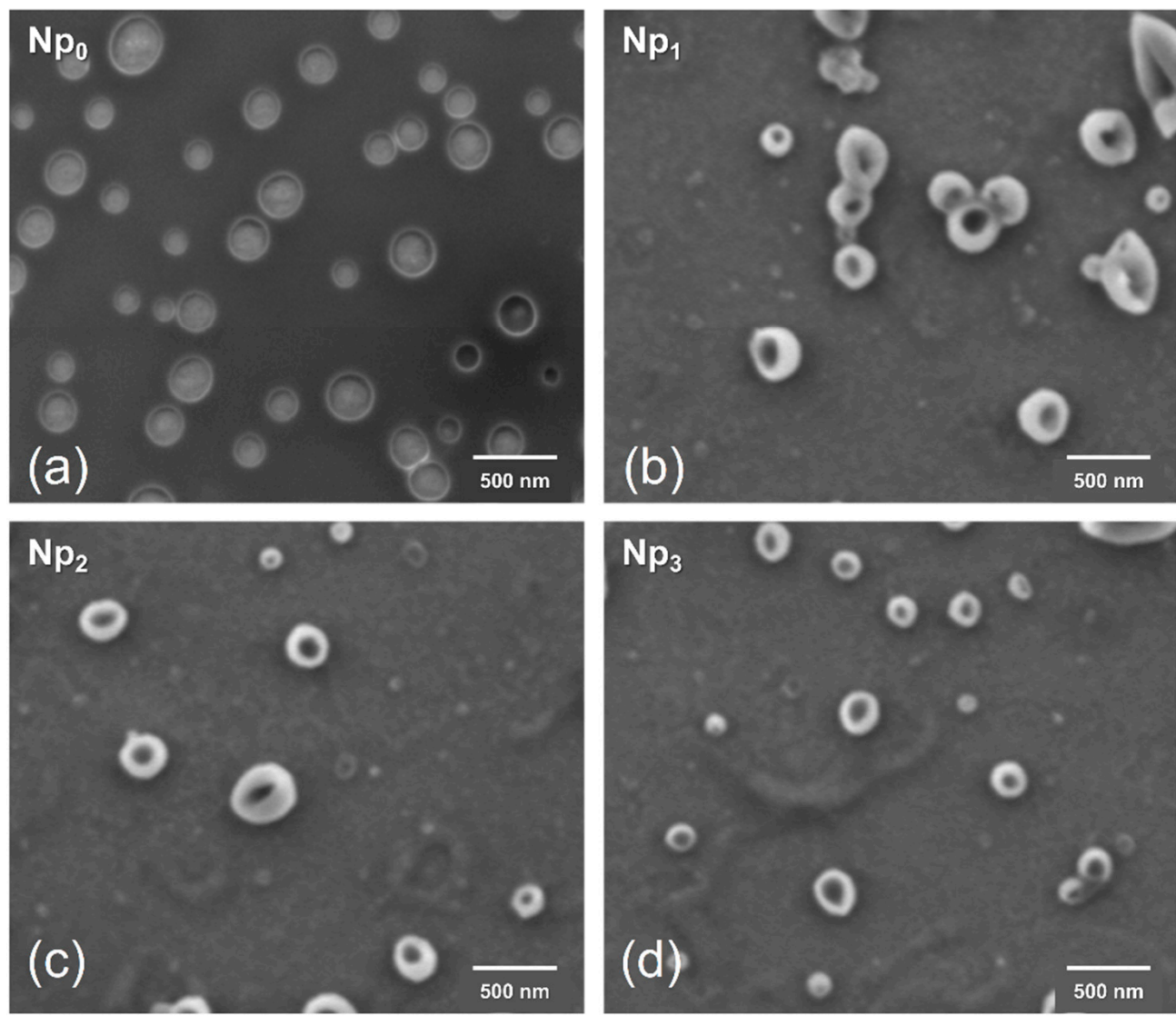

Figure 6. The behavior of size averages as a function of CS concentration. SEM imagen for (a) $\mathrm{Np}_{0}$; (b) $\mathrm{Np}_{1} ;$ (c) $\mathrm{Np}_{2}$ and (d) $\mathrm{Np}_{3}$ samples (scale bar $=500 \mathrm{~nm}$ ).

\subsection{Drug Loading (DL) and Encapsulation Efficiency (\%EE)}

In this study, the $\mathrm{Np}_{3}$ sample was selected due to physicochemical properties to determine the Average Encapsulation Efficiency (\%EE) and the the Drug Load (DL). The determination of \%EE and DL was performed for five vincristine sulfate concentrations $(10,20,30,40$ and $50 \mu \mathrm{g} / \mathrm{mL})$. The concentration of polymers was constant (Figure 7). It is evident that when the vincristine sulfate concentration rises, the LD goes up, and the \%EE goes down. At a $30 \mathrm{mg} / \mathrm{mL}$ concentration, a \%EE of $89.2 \pm 0.005$ and a DL of $2.77 \pm 0.05$ are observed. Although no data on EE and DL of vincristine encapsulated in PNIPAM Nps exist in the literature, the EE values obtained are high-ranking compared to those reported for other systems [46,47]. Likewise, DL values are comparable with other systems based on PNIPAM [48]. The values obtained suggest the high efficiency of the encapsulation and the suitability of the nanoplatform for use in drug delivery applications [49]. This sample was selected for controlled release testing. 


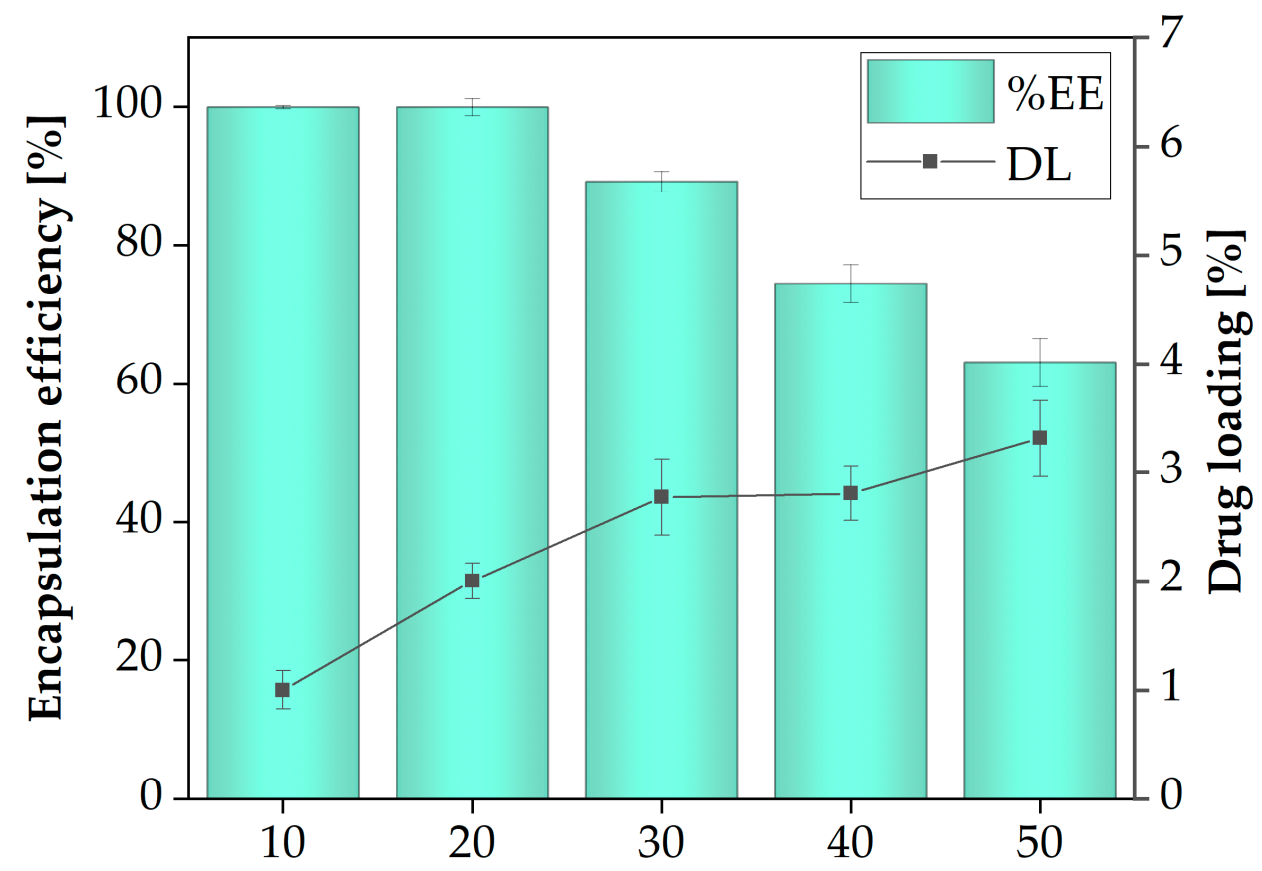

\section{Sulfate vincristine concentration $[\mu \mathrm{g} / \mathrm{ml}]$}

Figure 7. Sulfate vincristine loading and encapsulation efficiency of sample $\mathrm{Np}_{3}$.

\subsection{Effect of Temperature on Drug Delivery}

Model 1 fits the data well at 25,37, and $41{ }^{\circ} \mathrm{C}$, and the value of $\mathrm{R}^{2}$ decreases as a function of temperature (Table 1). At 37 and $41^{\circ} \mathrm{C}$, the release kinetics exhibits two welldefined stages (Figure 8). Model 2 fits well at 37 and $41^{\circ} \mathrm{C}$. We relate the first release stage to the diffusion of hydrophilic groups out of the particle, a classical Fickian-type diffusion. At temperatures above the LCST ( 37 and $41^{\circ} \mathrm{C}$ ), the concept of polymeric relaxation becomes relevant; the initial burst (first stage) in the release is so fast that it does not allow the inner polymeric layers to break the hydrogen bridges and expel the liquid inside them, steric-trapped inside the Nps. As the polymeric chains allow the hydrophilic molecules to migrate to the particle's surface, the second release stage occurs.

Table 1. Parameters of model 1 for the power-law equation, a classical diffusion Fickian-type.

\begin{tabular}{cccc}
\hline Temperature $\left({ }^{\circ} \mathbf{C}\right)$ & $\boldsymbol{K}_{\mathbf{1}}$ & $\boldsymbol{N}$ & $\mathbf{R}^{\mathbf{2}}$ \\
\hline 25 & 0.1168 & 0.2749 & 0.9754 \\
37 & 0.0447 & 0.3929 & 0.9781 \\
41 & 0.0985 & 0.3035 & 0.8911 \\
\hline
\end{tabular}

Experimental data at $37{ }^{\circ} \mathrm{C}$ shows $\mathrm{R}^{2}>0.996$ (Table 2) and $\mathrm{R}^{2}<0.978$ (Table 1) for model 2 and model 1, respectively. At $25^{\circ} \mathrm{C}$, it was not possible to adjust the data to model 2. Otherwise, the release fitted to model $1 \mathrm{R}^{2}>0.975$ in the swollen state $\left(25^{\circ} \mathrm{C}\right)$. We relate this limitation because, at $25^{\circ} \mathrm{C}$, the colloidal system is below the LCST temperature $\left(39{ }^{\circ} \mathrm{C}\right.$ for this sample $\mathrm{Np}_{3}$ ). Therefore, the relaxation stage does not occur. Inversely, when increasing the experimental temperature and approaching the LCST, an adjustment for a two-stage model occurs.

The constant $k_{1}$ is the front factor of the swelling ratio and, $n$ is the swelling exponent related to the water sorption mechanism.

The terms $h_{1}$ and $h_{2}$ are related to the speed of the release burst in the first and second stage, respectively. $A_{1}$ and $A_{2}$ are related to the duration of the first and second stage, 
respectively. The terms $\log x 01$ and $\log x 02$ represent the proportion released during the plateau between the two stages.

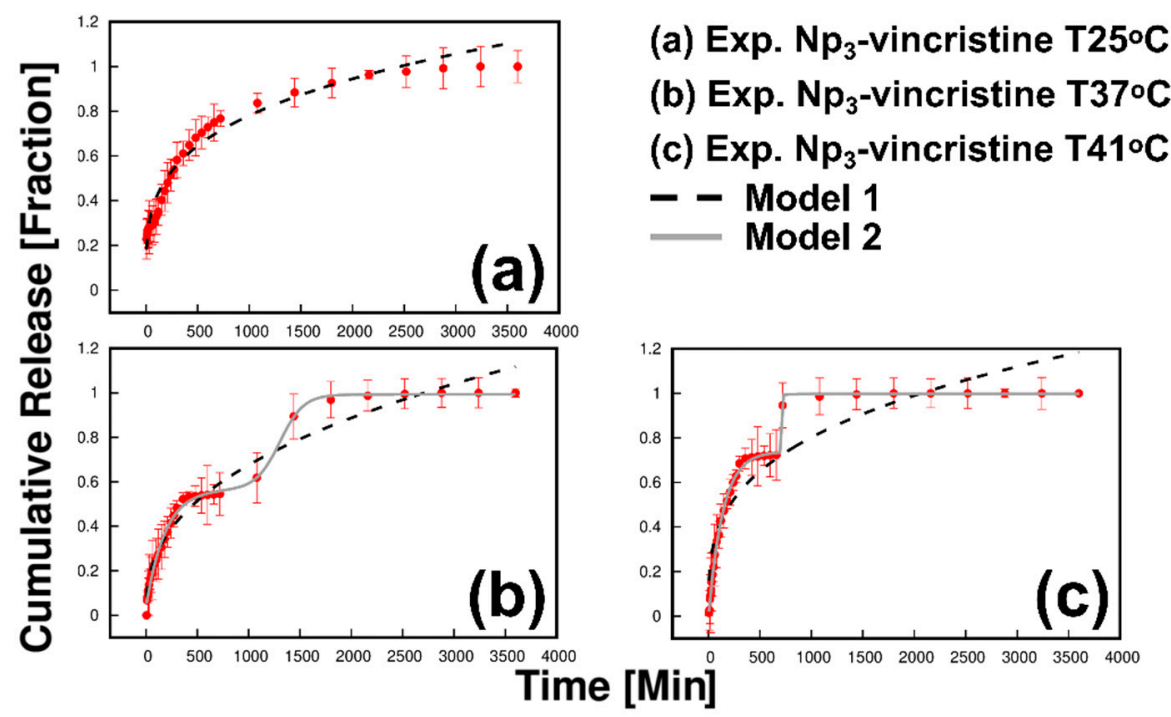

Figure 8. Correlation of mathematical models 1 and 2 of the release fraction of vincristine of the $\mathrm{Np}_{3}$-vincristine sample at different temperatures (a) $25^{\circ} \mathrm{C}$; (b) $37^{\circ} \mathrm{C}$ and (c) $41^{\circ} \mathrm{C}$.

Table 2. Parameters of model 2, the two-stage model (BiDoseResp).

\begin{tabular}{cccccccc}
\hline $\begin{array}{c}\text { Temperature } \\
\left({ }^{\circ} \mathbf{C}\right)\end{array}$ & $\boldsymbol{A}_{\mathbf{1}}$ & $\boldsymbol{A}_{\mathbf{2}}$ & $\log \mathbf{0 1}$ & $\log \mathbf{0 2}$ & $\boldsymbol{h}_{\mathbf{1}}$ & $\boldsymbol{h}_{\mathbf{2}}$ & $\mathbf{R}^{\mathbf{2}}$ \\
\hline 25 & - & - & - & - & - & - & - \\
37 & -9.7686 & 0.9931 & -526.4825 & 1304.0414 & 0.0037 & 0.0037 & 0.99639 \\
41 & -66.5933 & 0.9977 & -619.7001 & 715.7139 & 0.1503 & 0.1503 & 0.99853 \\
\hline
\end{tabular}

For experiments conducted at 37 and $41{ }^{\circ} \mathrm{C}$, data fitted for model $2 \mathrm{R}^{2}>0.996$ and their parameters are presented in Table 2 . The second release stage was promoted by structural relaxation of the polymer. Thereby, when the temperature approaches the LCST of the PNIPAM particle, the transitions from a swollen to a collapsed state result in the polymer chains' relaxation. The release by the relaxation mechanism is carried out near the LCST transition temperature $\left(32^{\circ} \mathrm{C}\right)$ (Figure 8$)$. We associate this change with developing the structural transition from a hydrophobic state to a collapsed arrangement. Increasing the temperature makes it evident that the colloidal system's temperature exceeded the LCST point (Figure 8). Therefore, diffusional phenomena (burst type release) are promoted by energy changes in the system. When the release system was at $41^{\circ} \mathrm{C}$, the fraction released for the first stage (diffusional) was around 0.8. All the above demonstrates that the burst type release is promoted by temperature increment. The data at 37 and $41^{\circ} \mathrm{C}$ show that the temperature near the LCST triggers the drug's extended-release (Figure 8).

The study of temperature through the mathematical model is beneficial in applications for biomedicine like personalized chemical therapy. We can conclude that temperature modifications help control the drug release mechanism and its concentration in the release. The adequate regulation in the drug dosage and release mechanism are beneficial in the advances of biomedicine. Because it is possible to design personalized drug release therapies and long-acting drugs, the effect of this potentiation can be achieved by taking advantage of the virtues of nanotechnology by confining the drug in the vicinity of the nano-excipient. 


\section{Conclusions}

In the present research, the CS concentration on the morphology, $\zeta$-potential and the hydrodynamic diameter of $\mathrm{Fe}_{3} \mathrm{O}_{4} @$ PNIPAM-CS systems were studied. When the polymerization's CS concentration was increased, the particle size decreased from 304 to $210 \mathrm{~nm}$, and the LCST of the polymeric matrix was shifted from 33 to $39^{\circ} \mathrm{C}$ successfully. Excess amino groups' contribution leads to inter-group repulsion and results in packaged polymeric structures caused by the spatial restriction. The electrostatic interactions between the NIPAM monomer and the OA layer yielded a complex formation. With the polymerization of NIPAM in the magnetic particles' vicinity, a significant change in particle size and $\zeta$-potential was obtained; this confirms its correct functionalization, resulting in a core-shell structure. The $\mathrm{Fe}_{3} \mathrm{O}_{4} @$ PNIPAM-CS systems preserve their sensitivity to magnetic and temperature stimuli. With a spherical morphology and a size of $210 \mathrm{~nm}$ in the dehydrated state, the $\mathrm{Np}_{3}$ sample demonstrates a desired magnetic and thermal response. The change in its hydrodynamic radius indicates its strong ability to transport and release hydrophilic molecules.

The sample $\mathrm{Np}_{3}$ has a well-defined polymeric shell. A stimuli-responsive $\mathrm{Np}_{3}$ sample loaded with the antineoplastic vincristine sulfate was evaluated as a drug delivery system using the power-law model and a two-stage model. At $25^{\circ} \mathrm{C}$, the drug was released by unrestricted diffusion. On the other hand, at $41^{\circ} \mathrm{C}$, a structural relaxation mechanism occurred, affected by the structural change upon exceeding LCST. According to the above, a helpful nanoplatform has been designed for versatile chemical therapy that provides high customization according to the requirements.

Author Contributions: Conceptualization P.A.H.-A., C.N.H.-T. and M.E.Á.-R.; methodology, P.A.H.-A., C.N.H.-T., N.G.-F. and A.G.L.-A.; formal analysis, M.E.Á.-R. and N.G.-F.; investigation, P.A.H.-A., C.N.H.-T., N.G.-F., A.G.L.-A., M.P.-J., J.L.I.-R. and M.B.-H.; writing-original draft preparation, P.A.H.-A., C.N.H.-T., A.G.L.-A., H.J.H.-V. and M.B.-H.; writing-review and editing, P.A.H.-A., C.N.H.-T., A.G.L.-A., M.P.-J. and J.L.I.-R.; project administration, P.A.H.-A. All authors have read and agreed to the published version of the manuscript.

Funding: This research was funded by Public Education of Mexico (SEP), CESUES-PTC-029.

Institutional Review Board Statement: Not applicable.

Informed Consent Statement: Not applicable.

Data Availability Statement: The data presented in this study are available on request from the corresponding author.

Acknowledgments: The authors express our gratitude to the Nanotechnology Graduate Program of the University of Sonora for its facilities. Pedro Hernandez thanks Ph.D. financial assistance from the National Council of Science and Technology of Mexico (CONACYT). The authors would like to thank Roberto Carlos Carrillo Torres for the assistance in SEM. The authors received no financial support for the research of this article.

Conflicts of Interest: The authors declare no competing financial interest.

\section{References}

1. Grande, A.H. Nanotecnología y nanopartículas magnéticas: La física actual en lucha contra la enfermedad. Rev. R. Acad. Cienc. Exact. Fís. Nat. 2007, 101, 321-327.

2. Wang, J.; Huang, N.; Peng, Q.; Cheng, X.; Li, W. Temperature/pH dual-responsive and luminescent drug carrier based on PNIPAM-MAA/lanthanide-polyoxometalates for controlled drug delivery and imaging in HeLa cells. Mater. Chem. Phys. 2020, 239. [CrossRef]

3. Coral, D.F.; Jenny, A.; Mera, J.A.M. Una guía para el estudio de nanopartículas magnéticas de óxidos de hierro con aplicaciones biomédicas. Parte II. Ing. Cienc. 2017, 13, 207-232. [CrossRef]

4. Wei, Z.; Zhao, W.; Wang, Y.; Wang, X.; Long, S.; Yang, J. Novel PNIPAm-based electrospun nanofibres used directly as a drug carrier for "on-off" switchable drug release. Colloids Surf. B Biointerfaces 2019, 182. [CrossRef]

5. Umapathi, R.; Reddy, P.M.; Kumar, A.; Venkatesu, P.; Chang, C.J. The biological stimuli for governing the phase transition temperature of the 'smart' polymer PNIPAM in water. Colloids Surf. B Biointerfaces 2015, 135, 588-595. [CrossRef] [PubMed]

6. Matsui, I. Nanoparticles for electronic device applications: A brief review. J. Chem. Eng. Jpn. 2005, 38, 535-546. [CrossRef] 
7. Alarcón-Payán, D.A.; Koyani, R.D.; Vazquez-Duhalt, R. Chitosan-based biocatalytic nanoparticles for pollutant removal from wastewater. Enzyme Microb. Technol. 2017, 100, 71-78. [CrossRef]

8. Kokardekar, R.R.; Shah, V.K.; Mody, H.R. PNIPAM Poly (N-isopropylacrylamide): A thermoresponsive "smart" polymer in novel drug delivery system. Med. Update 2012, 7, 60-63.

9. Bahl, S.; Nagar, H.; Singh, I.; Sehgal, S. Smart materials types, properties and applications: A review. Mater. Today Proc. 2020, 28, 1302-1306. [CrossRef]

10. Nasseri, R.; Deutschman, C.P.; Han, L.; Pope, M.A.; Tam, K.C. Cellulose nanocrystals in smart and stimuli-responsive materials: A review. Mater. Today Adv. 2020, 5. [CrossRef]

11. Kurakula, M.; Naveen, N.R. Prospection of recent chitosan biomedical trends: Evidence from patent analysis (2009-2020). Int. J. Biol. Macromol. 2020, 165, 1924-1938. [CrossRef] [PubMed]

12. Sanoj Rejinold, N.; Sreerekha, P.R.; Chennazhi, K.P.; Nair, S.V.; Jayakumar, R. Biocompatible, biodegradable and thermo-sensitive chitosan-g-poly (N-isopropylacrylamide) nanocarrier for curcumin drug delivery. Int. J. Biol. Macromol. 2011, 49, 161-172. [CrossRef] [PubMed]

13. Larson, N.; Ghandehari, H. Polymeric conjugates for drug delivery. Chem. Mater. 2012, 24, 840-853. [CrossRef]

14. Häfeli, U.O.; Sweeney, S.M.; Beresford, B.A.; Humm, J.L.; Macklis, R.M. Effective targeting of magnetic radioactive90Ymicrospheres to tumor cells by an externally applied magnetic field. Preliminary in vitro and in vivo results. Nucl. Med. Biol. 1995, 22, 147-155. [CrossRef]

15. Sadighian, S.; Rostamizadeh, K.; Hosseini-Monfared, H.; Hamidi, M. Doxorubicin-conjugated core-shell magnetite nanoparticles as dual-targeting carriers for anticancer drug delivery. Colloids Surf. B Biointerfaces 2014, 117, 406-413. [CrossRef] [PubMed]

16. Yuan, Q.; Venkatasubramanian, R.; Hein, S.; Misra, R.D.K. A stimulus-responsive magnetic nanoparticle drug carrier: Magnetite encapsulated by chitosan-grafted-copolymer. Acta Biomater. 2008, 4, 1024-1037. [CrossRef]

17. Alicia, J.D.; Javier, C.H. Nanopartículas magnéticas de zinc y calcio para aplicaciones en hipertermia magnética. Rev. Fac. Ing. 2016, 25, 89-98.

18. Honey Priya, J.; Rijo, J.; Anju, A.; Anoop, K.R. Smart polymers for the controlled delivery of drugs-A concise overview. Acta Pharm. Sin. B 2014, 4, 120-127. [CrossRef] [PubMed]

19. Ebadi, M.; Buskaran, K.; Bullo, S.; Hussein, M.Z.; Fakurazi, S.; Pastorin, G. Synthesis and cytotoxicity study of magnetite nanoparticles coated with polyethylene glycol and sorafenib-zinc/aluminium layered double hydroxide. Polymers 2020, $12,2716$. [CrossRef]

20. Petters, C.; Irrsack, E.; Koch, M.; Dringen, R. Uptake and metabolism of iron oxide nanoparticles in brain cells. Neurochem. Res. 2014, 39, 1648-1660. [CrossRef]

21. Hernández, P.; Lucero-Acuña, A.; Moreno-Cortez, I.E.; Esquivel, R.; Álvarez-Ramos, E. Thermo-magnetic properties of Fe 3 O $4 @$ poly(N-Isopropylacrylamide) core-shell nanoparticles and their cytotoxic effects on HeLa and MDA-MB-231 cell lines. J. Nanosci. Nanotechnol. 2019, 20, 2063-2071. [CrossRef]

22. Shi, S.F.; Jia, J.F.; Guo, X.K.; Zhao, Y.P.; Chen, D.S.; Guo, Y.Y.; Cheng, T.; Zhang, X.L. Biocompatibility of chitosan-coated iron oxide nanoparticles with osteoblast cells. Int. J. Nanomed. 2012, 7, 5593-5602.

23. Kean, T.; Thanou, M. Biodegradation, biodistribution and toxicity of chitosan. Adv. Drug Deliv. Rev. 2010, 62, 3-11. [CrossRef]

24. Islam, N.; Dmour, I.; Taha, M.O. Degradability of chitosan micro/nanoparticles for pulmonary drug delivery. Heliyon 2019, 5. [CrossRef] [PubMed]

25. Briceño, S.; Hernandez, A.C.; Sojo, J.; Lascano, L.; Gonzalez, G. Degradation of magnetite nanoparticles in biomimetic media. J. Nanopart. Res. 2017, 19. [CrossRef]

26. Kumar, B.; Jalodia, K.; Kumar, P.; Gautam, H.K. Recent advances in nanoparticle-mediated drug delivery. J. Drug Deliv. Sci. Technol. 2017, 41, 260-268. [CrossRef]

27. Das, M.; Shim, K.H.; An, S.S.A.; Yi, D.K. Review on gold nanoparticles and their applications. Toxicol. Environ. Health Sci. 2011, 3, 193-205. [CrossRef]

28. Alkhalil, A.; Strand, S.; Mucker, E.; Huggins, J.W.; Jahrling, P.B.; Ibrahim, S.M. Inhibition of Monkeypox virus replication by RNA interference. Virol. J. 2009, 6. [CrossRef] [PubMed]

29. Hernández Paredes, H.G. Efecto Antiproliferativo de la Betanina y Coadyuvante con Vincristina en Células de Leucemia Lingoblástica Aguda Tipo T. Master's Thesis, Universidad Autónoma de Querétaro, Santiago de Querétaro, Mexico, October 2018.

30. Fawcett, S.L.; Grant, I.; Hall, P.N.; Kelsall, A.W.R.; Nicholson, J.C. Vincristine as a treatment for a large haemangioma threatening vital functions. Br. J. Plast. Surg. 2004, 57, 168-171. [CrossRef]

31. Silverman, J.A.; Deitcher, S.R. Marqibo ${ }^{\circledR}$ (vincristine sulfate liposome injection) improves the pharmacokinetics and pharmacodynamics of vincristine. Cancer Chemother. Pharmacol. 2013, 71, 555-564. [CrossRef] [PubMed]

32. Esquivel, R.; Canale, I.; Ramirez, M.; Hernández, P.; Zavala-Rivera, P.; Álvarez-Ramos, E.; Lucero-Acuña, A. Poly(Nisopropylacrylamide)-coated gold nanorods mediated by thiolated chitosan layer: Thermo-pH responsiveness and optical properties. E-Polymers 2018, 18, 163-174. [CrossRef]

33. Lammel, T.; Thit, A.; Cui, X.; Mouneyrac, C.; Baun, A.; Valsami-Jones, E.; Sturve, J.; Selck, H. Trophic transfer of CuO NPs from sediment to worms (Tubifex tubifex) to fish (Gasterosteus aculeatus): A comparative study of dissolved Cu and NPs enriched with a stable isotope tracer (65Cu). Environ. Sci. Nano 2020, 7. [CrossRef] 
34. Kerli, S.; Alver, U.; Göğebakan, M. Investigation of the electrical properties of Al85Y9Ni6 metallic glass and formulation of the results. Glass Phys. Chem. 2020, 46, 189-193. [CrossRef]

35. Jiao, Y.; Gong, X.; Han, H.; Gao, Y.; Lu, W.; Liu, Y.; Xian, M.; Shuang, S.; Dong, C. Facile synthesis of orange fluorescence carbon dots with excitation independent emission for $\mathrm{pH}$ sensing and cellular imaging. Anal. Chim. Acta 2018, 1042, 125-132. [CrossRef]

36. Chen, G.; Hoffman, A.S. Graft copolymers that exhibit temperature-induced phase transitions over a wide range of pH. Nature 1995, 373. [CrossRef]

37. Huang, C.H.; Chuang, T.J.; Ke, C.J.; Yao, C.H. Doxorubicin-gelatin/ $\mathrm{Fe}_{3} \mathrm{O}_{4}$-Alginate dual-layer magnetic nanoparticles as targeted anticancer drug delivery vehicles. Polymers 2020, 12, 1747. [CrossRef] [PubMed]

38. Tong, S.; Quinto, C.A.; Zhang, L.; Mohindra, P.; Bao, G. Size-dependent heating of magnetic iron oxide nanoparticles. ACS Nano 2017, 11, 6808-6816. [CrossRef]

39. Schwertmann, U.; Cornell, R.M. The Iron Oxides: Structure, Properties, Reactions, Occurrence, and Uses; John Wiley \& Sons: New York, NY, USA, 2003.

40. Atabaev, T.S.; Kim, H.K.; Hwang, Y.H. Fabrication of bifunctional core-shell $\mathrm{Fe}_{3} \mathrm{O}_{4}$ particles coated with ultrathin phosphor layer. Nanoscale Res. Lett. 2013, 8, 1-6. [CrossRef]

41. Shagholani, H.; Ghoreishi, S.M.; Mousazadeh, M. Improvement of interaction between PVA and chitosan via magnetite nanoparticles for drug delivery application. Int. J. Biol. Macromol. 2015, 78, 130-136. [CrossRef]

42. Bruniaux, J.; Ben Djemaa, S.; Aubert, K.H.; Marchais, H.; Chourpa, I.; David, S. Stealth magnetic nanocarriers of siRNA as platform for breast cancer theranostics. Int. J. Pharm. 2017, 532, 660-668. [CrossRef]

43. Ali, E.M.M.; Elashkar, A.A.; El-Kassas, H.Y.; Salim, E.I. Methotrexate loaded on magnetite iron nanoparticles coated with chitosan: Biosynthesis, characterization, and impact on human breast cancer MCF-7 cell line. Int. J. Biol. Macromol. 2018, 120, 1170-1180. [CrossRef]

44. Kang, M.K.; Kim, J.C. FITC-dextran releases from chitosan microgel coated with poly(N-isopropylacrylamide-co-methacrylic acid). Polym. Test. 2010, 29, 784-792. [CrossRef]

45. Gong, Y.; Liu, Q.L.; Zhu, A.M.; Zhang, Q.G. One-pot synthesis of poly(N-isopropylacrylamide)/chitosan composite microspheres via microemulsion. Carbohydr. Polym. 2012, 90, 690-695. [CrossRef] [PubMed]

46. Dawes, G.J.S.; Fratila-Apachitei, L.E.; Mulia, K.; Apachitei, I.; Witkamp, G.J.; Duszczyk, J. Size effect of PLGA spheres on drug loading efficiency and release profiles. J. Mater. Sci. Mater. Med. 2009, 20, 1089-1094. [CrossRef] [PubMed]

47. Cai, K.; He, X.; Song, Z.; Yin, Q.; Zhang, Y.; Uckun, F.M.; Jiang, C.; Cheng, J. Dimeric drug polymeric nanoparticles with exceptionally high drug loading and quantitative loading efficiency. J. Am. Chem. Soc. 2015, 137, 3458-3461. [CrossRef]

48. Yar, Y.; Khodadust, R.; Akkoc, Y.; Utkur, M.; Saritas, E.U.; Gozuacik, D.; Acar, H.Y. Development of tailored SPION-PNIPAM nanoparticles by ATRP for dually responsive doxorubicin delivery and MR imaging. J. Mater. Chem. B 2018, 6, 289-300. [CrossRef]

49. Ahmad, N.; Ahmad, I.; Umar, S.; Iqbal, Z.; Samim, M.; Ahmad, F.J. PNIPAM nanoparticles for targeted and enhanced noseto-brain delivery of curcuminoids: UPLC/ESI-Q-ToF-MS/MS-based pharmacokinetics and pharmacodynamic evaluation in cerebral ischemia model. Drug Deliv. 2014, 7544, 1-20. [CrossRef] [PubMed] 